\title{
SOME PHASES OF THE NEW CHECK COLLECTION SYSTEM
}

\author{
By Gordon B. Anderson, A.M.,
}

Instructor in Finance, Wharton School of Finance and Commerce, University of Pennsylvania.

It is not the purpose of this article to discuss all phases of the check collection system under the Federal Reserve Act, but to take up several fundamental problems with which the system of intra-district collection already inaugurated has to contend. This subject affects not only the bankers, both large and small, but also the business man who uses checks and drafts in the payment and collection of accounts.

The enormous volume of checks used daily in the transaction of business in the United States has created a problem which bankers of the country find very difficult to solve satisfactorily. This problem is by no means a new one but at this time the national agitation for a remedy is more widespread. In traming the Federal Reserve Act considerable attention was directed to this subject, with the result that provisions were made facilitating a solution, national in scope. The act, to a large degree, leaves the solution of the check collection problem to the Federal Reserve Board and the Federal reserve banks. In general, the law provides that a Federal reserve bank may receive on deposit from its member banks not only cash, but checks and drafts drawn upon other solvent members. This implies that the reserve bank has the power to collect these items. The law further provides that each reserve bank "shall receive on deposit at par from member banks . . . . checks and drafts drawn upon any of its depositors." In other words, the reserve bank is compelled to accept at par the checks drawn on its members when deposited by a member. The law further states that this does not necessarily mean free of all charge, for "the Federal Reserve Board shall by rule, fix the charges to be collected by the member banks from its patrons whose checks are cleared through the Federal reserve bank and the charge which 
may be imposed for the service of clearing or collection rendered by the Federal reserve bank."

That the Board fully realizes the importance of the clearing functions and its responsibility for the success of the system is evident, for in the first annual report is found the following statement: "From the beginning, the Board has regarded the organization of these clearing functions as one of the most important responsibilities with which it is charged under the Act, as well as one of its most difficult and intricate problems."

The committee of experts that advised and coöperated with the Board in preparing a plan of organization for the reserve banks recommended in part as follows:

It is strongly believed and recommended that a complete and thorough clearing system shall be inaugurated by every Federal reserve bank at the earliest possible moment consistent with success. This system should further be continued and extended as rapidly as is reasonably possible until it extends to all classes of operations and provides for the clearing of items drawn on both member and non-member banks. The facilities of the reserve banks should be used both locally and for out-of-town checks in the broadest possible sense and under conditions which will place the member banks upon a satisfactory basis of competition with non-members while giving to the customer of member banks the advantage of a system of par collection wherever possible and of collection at cost wherever charge must be made. . . . Having in mind the fact that the banks cannot perform their full functions in this respect at the very outset, it is, however, recommended that they start only with a partial system of clearings, subsequently extending this as they become able to do so.

The matter of carrying into effect the collection departments of the several reserve banks was left to each bank individually. However, all systems are practically alike. For the present, the system provides for intra-district clearings only, ${ }^{1}$ that is checks received from and drawn on member banks of the same district. All members of the Federal reserve system are eligible to membership in the collection system of their respective reserve banks. Membership in the collection system is voluntary and it is provided that members may withdraw upon thirty days' notice. The reserve bank acts as agent only, receiving and forwarding the items, assuming no responsibility for final payment. The member bank agrees to abide by all regulations governing the system. Members basis.

1 Drafts on other Federal reserve banks are received on a delayed credit 
are given immediate credit ${ }^{2}$ for items payable on demand which are drawn on members of the collection system in their district, if presented at the reserve bank before two o'clock (twelve o'clock Saturday), and agree to be charged immediately for all checks drawn on them, received at the Federal reserve bank from members of the collection system. In other words, the arrangement is a reciprocal plan. Further it is agreed that the reserve of the member bank which is kept with the reserve bank is not to be impaired; but, that a sufficient fund, to be determined by experience, over and above the reserve, is to be maintained to cover collection debts. Although the system is known as a collection system the Federal reserve bank really acts as a clearing house for its members.

The system does not pretend to supersede methods already efficient in check collection-of which the most common illustration is the city clearing house which performs admirably the local check clearing service among its members. Where banks located in adjoining communities can collect items more efficiently by direct communication than could be done through their reserve bank located at a point more remote-for the element of time is all important-the reserve bank does not expect or desire to handle the items.

The system of deposited reserves under the National Bank Act is responsible for a large part of the difficulty which we are now experiencing in solving this problem. Roughly speaking there are two classes of banks, under the National Bank Act, city and country banks. The city banks are authorized by law to hold a considerable part of the reserves of the country banks. These reserves have been built up and maintained in part by the shipment of currency but the greater part-probably 95 per cent of such balances-represents checks, drafts and other items drawn upon banks in other localities which have been sent by the country bank to its city correspondent for credit and collection. Thus, upon this city agent has fallen, though not against his will, the burden of collecting these items, in other words, converting them into available loanable funds. The country banker has not as a rule undertaken to collect these checks individually, for because of competition for accounts the reserve city banker has performed this service free

${ }^{2}$ District No. 12 (San Francisco) is working on a deferred credit and deferred debit basis, based upon the time required to forward the check to its destination and receive a remittance for it. 
of charge or at a very small cost. On the other hand it has been the reserve balances which the country banker has maintained in the city bank that have compensated the city bank for this collection service rendered. In addition the city banker pays a small rate of interest on these balances, usually 2 per cent. In some cases the arrangement is put upon a more favorable basis for the country banker, as the reserve agent sends to the country banker all checks drawn on the banks in the locality of the correspondent. The country banker collects these items and remits by a draft drawn upon his city correspondent, after deducting a collection charge for the service.

It is important to note that, generally speaking, the city banks have been largely exchange paying banks, contrasted with the country banks which have been exchange charging banks. When a system is about to be introduced whereby exchange charges are to be regulated to the point of elimination, if possible, it is the exchange charging bank which is least enthusiastic. The country banker has felt that the elimination of exchange charges is a reduction of his profits, while the exchange paying bank-the city bank-has been glad to join the system because it is thereby enabled to reduce expenses. An examination of the roster of banks which have joined the voluntary reciprocal collection system inaugurated by the reserve banks, shows that this situation has developed. The city banks almost without exception have gone into the system, whereas less than one third of the country national banks have agreed to join the voluntary collection system.

Students of banking reform and prominent bankers were unanimous in the opinion that one of the primary purposes to be accomplished by the Federal Reserve Act was the mobilization of the reserves of the national banks, which heretofore had been widely scattered and hence were unavailable in times of panics. As to whether all or only a portion of these reserves should be mobilized in the hands of the reserve banks was a matter upon which a difference of opinion existed. The Reserve Act is framed upon the principle that all of the reserves of member banks shall eventually be carried either in the vaults of the member bank or on deposit with the reserve bank. In other words, the old system by which the country banks carried a part of their reserve with the city banks, is to be uprooted, the change to be accomplished by graduated 
stages reaching completion in November, 1917. It was pointed out, while the Reserve Act was under consideration, that if the reserves were shifted, some provision must be made for handling the collection of checks drawn on the banks in distant localities, heretofore undertaken by the city institutions. The Reserve Act met this problem by providing that the Federal reserve banks should undertake this work.

But the inauguration of the collection service by the reserve banks rests upon even broader ground than the necessity due to the shifting of reserves. There has been for years a widespread and continuous criticism of the comparative inefficiency of existing collection methods. The city banks have handled the physical problem of their transit work with skill and comparatively small cost, but with attendant disadvantages. The disadvantages were very well set forth by Mr. C. R. McKay, Deputy Governor of the Federal reserve bank of Chicago:

First: Excessive exchange charges;

Second: Absorption of exchange charges by the collecting banks;

Third: Indirect routing of checks to avoid exchange charges chiefly caused by clearing house rules governing exchange charges;

Fourth: The maintenance of reserve balances with banks for the sole purpose of getting items on which to charge exchange;

Fifth: The carrying of compensating balances with collecting banks solely for the purpose of obtaining par territory;

Sixth: Paying interest on uncollected funds;

Seventh: Paying checks drawn against uncollected funds;

Eighth: Padding of reserves with items in transit.

From the standpoint of the member banks the present difficulty is not merely a transit problem but is more of a reserve problem. We have seen that the deposited reserve of the country banker was built up in the city banks mostly by the deposit of checks and drafts with a very small percentage of cash. The items so forwarded are immediately counted by the country bank as reserve, when mailed to the city reserve agent, although they are not received and collected by the city bank until several days later. This condition creates what is known as a paper reserve, or a reserve, a large part of which consists of uncollected checks in transit.

As one of the prime objects of the Federal Reserve Act is to have real mobilized reserves, the first factor to be eliminated is this paper reserve, in transit, or "float" as it is sometimes called by 
bankers. The country bank will not be able to count these items in transit as part of its reserve. The Federal reserve banks, with the exception of San Francisco, operate upon the principle of immediate debit and credit, so that, unlike the practice heretofore followed by the city banks, checks drawn upon country banks are immediately charged to the account of the country bank, rather than as heretofore sent to the country bank and paid for some days later when the draft in payment for them is received by return mail. The privilege heretofore enjoyed by the country bank of counting checks as part of their reserve as soon as put in the mail, will be little if any restricted. The great loss will be that checks drawn upon the country bank will be charged against the country bank at once, rather than sent back for collection and remitted for several days later. The immediate problem involved in this change has been well set forth by the Clearing Committee of the Federal Reserve Agents in its recent report presented to the Federal Reserve Board:

If all member banks joined the collection system and did business only with the reserve bank, each country and reserve city bank would be required to increase the reserve carried to an amount sufficient to offset the uncollected checks which are now constantly in transit to its reserve agents and are counted by it as reserves.

It is clear that the assumption of such a float will entail a distinct hardship on the country and reserve city banks. The hardship will be felt by them not only because it will reduce their loanable funds and their earnings, but because it will handicap them in competing with state banks. It is probable that until they have had time to adjust themselves and educate their depositors to carry their float the reserve banks will find it necessary to be somewhat lenient and share such portion of the burden as their resources will permit. It seems clear, however, that the development of the Federal reserve collection systems will inevitably, by prompt collections, materially reduce the proportions of the present float.

Having for so many years been able to count this float as reserve, it is probable that the complete assumption of it by the member banks can only be brought about by ruling of the Comptroller or by the imposition of the penalty for deficient reserves authorized by the Federal Reserve Act. The latter method would doubtless cause great dissatisfaction. The former is, therefore, to be preferred, but, in our opinion, it should not be attempted until the Comptroller has secured an agreement with all or nearly all state bank supervisors to make a joint ruling, effective after reasonable notice. At the same time, a study might profitably be made of what should constitute "net deposits" in calculating reserves, for adoption uniformly by supervising authorities. It is our belief that the excessive reserves now held by the banks make the present an especially favorable time to endeavor to effect this reform. 
The majority of the national banks object to the practice of the reserve banks immediately crediting and charging a member bank's account for checks presented by it or on it. They prefer the method by which the reserve banks would send the items through to the payee bank on a remittance basis. The member banks point out that under the present system of immediate charge and credit they do not know at any one time what are their balances with the reserve bank. Even the daily statement rendered to each member does not seem to overcome the objection. However, this is an objection which should adjust itself as the system progresses when the banks can determine the normal collection balance to be maintained. Thus far it has been found that many of the accounts have been overdrawn, that is, the reserves have not only been impaired, but in some cases eliminated entirely and the reserve bank has had to carry this so called overdraft or "float."

The national banks are clearly approaching a point where they must make a momentous decision. The natural conservation of bankers and the unwillingness to try experiments will induce many to adhere as long as possible to the old system of collections. As the Federal Reserve Act requires the balances of the reserves to be transferred during the course of the next two years from the city banks to the Federal reserve banks, conditions will be radically changed.

As the committee report, referred to above, well states:

The tangle of reciprocal collection arrangements which the competition of half a century has developed will be unraveled and ended. Country and reserve city banks will, therefore, be brought face to face for the first time with the problem of collecting their foreign items. Reserves with reserve agents will no longer provide and pay for their service. Clearly the service cannot be had for nothing; some one must pay the cost. Checks now count as reserves and the reserves carry the cost, but when the reserves have been completely transferred this will not be so. The cost will fall primarily on the bank which receives the foreign item on deposit. If the bank is unwilling to bear the cost, it must obviously impose it upon the person depositing the foreign item by either exacting a charge, deducting interest, or compelling a larger balance to be kept. Now that the cost of collecting foreign items is to be shifted from the reserve agent to the bank of original deposit, the latter must do just what the former has done-analyze its accounts and require those who deposit foreign items to keep compensating balances.

Clearly, if the Federal reserve system deprives member banks of their present collection facilities, it must provide a substitute; not only must it do this as a matter of both justice and law, but it should do it as a matter of policy as well. 
Numbers are essential to the ultimate success of the collection system of the Federal reserve banks. At present because of the small membership in most districts, a member bank finds perhaps 90 per cent of its checks uncollectable through the reserve bank collection system, so that the present service does not appreciably lighten the transit work of the average bank. The system to be effective must enable the member banks to dispose of all of its outof-town checks at the Federal reserve bank. Members of the Federal reserve system (national banks, and state banks which have joined) can be brought into the collection system by a mandatory order of the board changing the system from a voluntary to a compulsory participation. In view of events since the inauguration of the system it is very probable that such a change shall take place. Sentiment expressed by the Federal reserve banks favors a mandatory system. Three districts are directly opposed to the mandatory plan" while seven express themselves, in some cases with more or less qualification, in favor of the introduction of a mandatory system, most of the banks regarding this as necessary if the plan is to become fully effective." 3 This is concluded from statements made by the Federal reserve bank officials, several of which are included below:

It will certainly be necessary for the Board to issue a mandatory order before even the present plan would be of sufficient scope to reach a moderate point of efficiency. Many of the banks have indicated to us that they would not come in unless compelled to do so, and would not accept the mandatory order kindly by reason of the great loss of exchange.

. . . . the voluntary collection system should be given about six months more to operate before deciding as to whether it is successful or not. Banks which have joined it are now advertising the fact that checks on them are par in - We believe this action will oblige other banks to join the collection system, and that economic pressure will come from depositors of the banks and from the merchants who now have to pay exchange charges which will influence more banks to assent to the collection system.

It may be necessary, and, in my opinion, will likely be desirable, that the Board make the plan compulsory before success is assured.

We believe that it will be necessary that the Board issue a mandatory order compelling banks to join the check-collection system in order that the member banks may realize the full benefit of the arrangement. Member banks generally expected to be compelled to join the check-collection system, and when the voluntary plan was offered a large majority preferred to defer joining until they

- Federal Reserve Bulletin, August, 1915, p. 194. 
could observe the effects of the operation of the plan with such banks as decided to join. We believe that if the plan were made mandatory it would in a reasonable time commend itself to our member banks, but for the present the fear of the necessity of maintaining excess balances, on which no interest is allowed, and the disinclination to reliquish exchange profits deters many country banks from entering the voluntary system.

A mandatory order would by no means solve the entire problem, for checks on non-member state institutions are a large factor. Provision should be made for handling these items by each reserve bank for its members. These checks on non-members would have to be handled on a collection basis, the reserve banks forwarding the checks either directly, or through a member bank in the same town, and upon presentation, a draft be sent to the reserve bank upon receipt of which the reserve bank would credit the account of the member that turned the checks over for collection.

After the collection system was made compulsory it is very likely that within a short time that checks on non-member state banks would be discriminated against, because the member bank's check, due to efficient collection methods, would be accepted at par, especially within a reasonable distance, ${ }^{4}$ whereas the check of a non-member state bank would not be payable at par, but would be subject to an exchange charge. Should this be the case, depositors of state banks would bring pressure to bear and this influence would tend to force the other state institutions into the federal reserve system. Check collection will be an advantage conferred by the Federal reserve system which the state banks cannot afford to be without, because, so long as the business man continues to use individual checks in payment of accounts, he is vitally interested in having his check circulate at par or on an even basis with other men's checks. Thus, if the Federal reserve bank has better facilities for handling this business, it can set the standard and regulate domestic exchanges to the point where the state banks must either take advantage of them or suffer.

The Federal reserve system of check collection is no doubt a great movement forward in handling this troublesome problem.

4 It is true that agencies outside of the reserve banks will become active in organizing collection systems to care for state bank checks, but it is difficult to comprehend a system which would be as extensive as the proposed system conducted by the twelve reserve banks, including intra-district and inter-district collection. 
With the introduction of inter-district collection it will no doubt gain popularity. The significant fact is not whether the Federal reserve banks will handle all the checks in the country, but that a nation-wide movement has been stimulated and the handling of out-of-town checks is being taken up by almost every community of importance in the United States. The country clearing house has been advocated by bankers a great many years and some cities have taken it up with very successful results. Observation of such systems in operation in Boston, Kansas City and other places makes one feel confident that the Federal reserve system of check collection is not only feasible but has little chance of failure. 